\begin{tabular}{lllllllll}
$\mathbf{D}$ & $\mathbf{O}$ & $\mathbf{K}$ & $\mathbf{U}$ & $\mathbf{M}$ & $\mathbf{E}$ & $\mathbf{N}$ & $\mathbf{T}$ & $\mathbf{Y}$ \\
\hline
\end{tabular}

VOX PATRUM 27 (2007) t. 50-51

\title{
PATRYSTYCZNA KATECHEZA BENEDYKTA XVI
}

Podobnie, jak Jan Paweł II, który Ojcom Kościoła i rocznicom Kościoła starożytnego poświęcił aż 11 okolicznościowych Listów Apostolskich, a w swoich wystąpieniach wielokrotnie się do nich odwoływał, tak również papież Benedykt XVI często ich, zwłaszcza w swoich katechezach, jako świadków Tradycji prezentuje; owszem, ma do tego lepsze, niż jego poprzednik, teologiczne przygotowanie: już w seminarium duchownym we Fryzyndze studiując filozofię spotkał się z personalizmem, który w jego wypadku, jak pisze w swoich pamiętnikach, ,wiązał się niemal samoistnie z myślą św. Augustyna, który w swoich Wyznaniach wyszedł mu naprzeciw w całej swej namiętności i ludzkiej głębi. Miał natomiast trudności z przyjęciem myśli św. Tomasza z Akwinu, którego krystaliczna logika wydawała mu się zbyt zamknięta w sobie, zbyt bezosobowa i sztywna"1.

Podczas późniejszych studiów w seminarium w Monachium najbardziej mu odpowiadała dogmatyka ks. prof. M. Schmausa, który, jak znów zapisze w pamiętnikach, zdystansował się od schematu neoscholastycznego, ,prezentował żywą katolicką naukę, czerpiącą natchnienie $\mathrm{z}$ ducha ruchu liturgicznego oraz nowego zainteresowania Ojcami i Pismem, które rozwinęło się po I wojnie światowej"2. Ojcowie Kościoła i ich nauka stawały mu się coraz bliższe, co znalazło swój wyraz i pogłębienie w podjętym temacie pracy doktorskiej pt. Lud i dom Boży w nauce św. Augustyna o Kościele, obronionej w lipcu 1953 roku. Tematyka ta stawała mu się również coraz bardziej znana, bo w tym właśnie okresie stykał się z pismami Henriego de Lubaca i Hansa Urs von Balthasara, którzy przekazali mu „,nową i głębszą relację z myślą Ojców” oraz bardziej ogólnie - z teologią i wiarą ${ }^{3}$. Gdy w tym czasie przygotowywano się do ogłoszenia dogmatu o wniebowzięciu N.M. Panny, a Pius XII poprosił wydziały

${ }^{1}$ Cytuję za: A. Tornielli, Wspótpracownicy prawdy. Biografia Benedykta XVI, thum. B. Tomaszek, Kraków 2005, 50; J. Ratzinger, Moje życie. Autobiografia Benedykta XVI (= Ratzinger), tłum. W. Wiśniowski, Częstochowa 2005, 50.

2 Tornielli, Wspótpracownicy prawdy, s. 51; Ratzinger, s. 57.

3 Tornielli, Wspótpracownicy prawdy, s. 55; Ratzinger, s. 72. 
teologiczne o wypowiedzenie się na ten temat, ogół odpowiedzi niemieckich był zdecydowanie negatywny, bo Tradycję, jak on sam później napisze w pamiętnikach, utożsamiano z tym, co można było udokumentować w tekstach" Profesor patrologii w Würzburgu B. Altaner wykazał nawet na podstawie naukowo niepodważalnych przesłanek, że nauka o wniebowzięciu Maryi była nieznana przed V wiekiem, a zatem nie może „być częścią tradycji apostolskiej”, wniosek zaś ten poparli także profesorzy z Monachium. W odpowiedzi na te postawy przyszły prefekt Kongregacji Nauki Wiary inaczej spojrzy na Tradycję i napisze: „Argument jest bez zarzutu, jeśli rozumie się tradycje w znaczeniu ścisłym jako przekazywanie już ustalonych treści i tekstów. Ale jeśli tradycję rozumie się jako żywy proces, poprzez który Duch Święty prowadzi nas do całej prawdy i uczy nas rozumieć to, czego wcześniej nie byliśmy w stanie pojąć, wtedy następujące «przypomnienie» może pozwolić dostrzec to, co wcześniej zostało niezauważone, a jednak było już dane, już "przekazane» w pierwotnym słowie" ${ }^{5}$.

Gdy później podczas Soboru Watykańskiego II dyskutowano o źródłach Objawienia, pod których pojęciem rozumiano tradycyjnie Pismo Święte i Tradycję, oraz o ich wzajemnym stosunku i relacji do Magisterium Kościoła, dla ks. J. Ratzingera, najpierw z polecenia kard. J. Fringsa - teologa soborowego, a potem biskupa - uczestnika tych dysput, jak sam pisze: „,problematyczny stał się także kontekst tradycji, jako że, wychodząc od metody historycznej, nie da się zrozumieć istniejącej obok Pisma i sięgającej aż do Apostołów tradycji ustnej, która - obok Biblii - mogłaby stanowić źródło historycznego poznania [...]. Objawienie jest czymś żywym, czymś większym - aby było Objawieniem, musi osiągnąć swoje przeznaczenie i zostać przyjęte i zrozumiane [...]. Nie jest meteorytem, który spadł na ziemię i leży gdzieś jako masa skalna, z której można pobrać próbki minerałów, zanieść do laboratorium i przeanalizować"6. Ponadto w przeciwieństwie do K. Rahnera, którego „teologia - jak pisze w pamiętniku - mimo wcześniejszego kontaktu z lekturą Ojców Kościoła, była całkowicie ukształtowana przez tradycję suarezjańskiej scholastyki i jej nowej recepcji w świetle niemieckiego idealizmu i dzieł Heideggera oraz zbyt spekulatywna i filozoficzna, w której Pismo i Ojcowie nie odgrywali zbyt dużej roli, a wymiar historyczny miał niewielkie znaczenie”, on ,ze względu na swoje wykształcenie czuł się bardziej związany z Pismem i z Ojcami oraz myśleniem typowo historycznym"7. Takie "przygotowanie biblijne i patrystyczne" oraz współpraca z ewangelickim patrologiem Ulrichem Wickertem ułatwiały mu nauczanie dogmatyki ${ }^{8}$.

\footnotetext{
4 Tamże, s. 54.

5 Tamże.

6 Tamże, s. 70-71.

7 Ratzinger, s. 108.

${ }^{8}$ Por. tamże, s. 110 i 120.
} 
Ze wszystkich Ojców Kościoła najbardziej interesowała go nauka i sylwetka św. Augustyna, czego wyrazem był m.in. wspominany temat pracy doktorskiej; często mówił o jego życiu i o tym, co mu zawdzięcza, jako człowiek, kapłan, teolog i pasterz. Fascynowała go jego postać jako człowieka szukającego uporczywie prawdy i Boga, do czego się przyznaje w jednym z przemówień do duchownych i alumnów rzymskiego seminarium duchownego: „Fascynowała mnie przede wszystkim wielka osobowość św. Augustyna jako człowieka, który [...] musiał prowadzić duchową walkę, by stopniowo znajdować dostęp do słowa Bożego, do życia z Bogiem, aż do chwili, gdy powiedział wielkie «tak» Jego Kościołowi. Ta bardzo ludzka droga pozwala nam także dzisiaj zobaczyć, jak nawiązuje się kontakt z Bogiem, jak wszystkie opory naszej natury muszą być potraktowane z całą powagą i tak ukierunkowane, byśmy na koniec mogli powiedzieć Panu wielkie «tak»”. Całą „swą teologię rozwijał - jak zapisze w pamiętniku - w nawiązywaniu dialogu ze św. Augustynem"10. Przy innej okazji stwierdził, że gdyby miał zabrać na bezludną wyspę tylko dwie książki, to wybrałby Pismo Święte i Wyznania św. Augustyna. Nie jest też bez znaczenia, że w swoich ustnych i pisemnych papieskich wypowiedziach pierwszych dwóch lat swego pontyfikatu (20052006) ponad 40 razy imiennie go cytował $^{11}$, a swoją pierwszą encyklikę „Deus caritas est” powierzył Kościołowi i światu od jego grobu w Pawii, jako żywego pulpitu stwierdzając: „tu przed grobem św. Augustyna, chciałbym w sposób symboliczny ponownie powierzyć Kościołowi i światu mą pierwszą encyklikę, która zawiera właśnie to główne przesłanie Ewangelii „Deus caritas est - Bóg jest miłością" (1J 4, 8. 16). Ta encyklika, zwłaszcza jej pierwsza część, wiele zawdzięcza myśli św. Augustyna, który był zakochany w miłości Bożej, wysławiał ją, rozważał, głosił we wszystkich swoich pismach, a przede wszystkim dawał jej świadectwo w swej pasterskiej posłudze"12. Jako teolog i biskup dopatrywał się z nim podobnych kolei życia, przypominając, że w pewnym momencie obaj musieli zrezygnować z pracy naukowej, by służyć ludowi Bożemu jako biskupi - Augustyn w Hipponie a on w Monachium, oraz walczyć o zachowanie czystości wiary - Augustyn jako apologeta Koś-

${ }^{9}$ Il si del sacerdozio mi ha accompagnato ogni giorno della mia vita, OsRom 147 (2007) nr 41, s. 6, thum. OsRomPol 28 (2007) nr 6, s. 3; zob. także, Il sacerdote è il pastore che precede il popolo di Dio sulla strada della preghiera, del perdono, della carità, OsRom 147 (2007) nr 45, s. 6-7.

${ }^{10}$ Ratzinger, s. 72; por. J.L. Allenjh, Papiez Benedykt XVI. Biografia Josepha Ratzingera, tłum. R. Bartołd, Poznań 2005, 58-60 (Św. Augustyn); K. Rüdiger Mai, Benedykt XVI. Jego życie, jego wiara, jego dązenia, tłum. M. Misiorny, Warszawa 2005, 74-76 (Augustyn i Ojcowie).

11 Por. Insegnamenti di Benedetto XVI, vol. I-II/1-2.

12 Qui, davanti alla tomba di Sant'Agostino, riconsegno idealmente alla Chiesa e al mondo la mia prima Enciclica „Deus Caritas est”. Przemówienie podczas nieszporów w Bazylice św. Piotra «in Ciel d'Oro» w Pawii (22 IV 2007), OsRom 147 (2007) nr 92, s. 14; przekład OsRomPol 28 (2007) nr 6, s. 14; zob. S. Mattei, Da quel "pulpito» vivente che è Agostino il Papa riconsegna la sua prima Enciclica „Deus caritas est”, OsRom 147 (2007) nr 92, s. 15. 
cioła w Afryce, a on jako prefekt Kongregacji Nauki Wiary w Rzymie. Gdy w 1977 r. papież Paweł VI mianował go arcybiskupem Monachium i Freising, to przy wyrażaniu zgody na przyjęcie tego urzędu pomocą był mu, jak zanotował w pamiętniku, właśnie św. Augustym, zwłaszcza jego refleksje o życiu teologa i biskupa. Do swego biskupiego herbu wybrał dwa symbole - muszlę i niedźwiedzia. Muszla miała być znakiem naszego ludzkiego pielgrzymowania oraz miała przypominać mu legendę o dziecku i św. Augustynie medytującym tajemnicę Trójcy Świętej. „Muszla jest dla mnie symbolem mojego wielkiego mistrza Augustyna, symbolem teologicznej pracy i wielkości tajemnicy, która sięga dalej niż cała nasza wiedza". Niedźwiedzia natomiast zaczerpnął z legendy o św. Korbinianie (670-725), pierwszym misjonarzu Bawarii i założycielu diecezji Freising. Według tej legendy niedźwiedź miał rozszarpać podróżującego do Rzymu konia Korbiniana, za co ten obciążył go swoim bagażem i polecił zawieźć aż do Wiecznego Miasta, gdzie dopiero tam został uwolniony. „Ten obciążony przez świętego niedźwiedź - kontynuuje Benedykt XVI w swoim pamiętniku - przypomina mi o medytacjach psalmów u św. Augustyna. Wiersze 21 i 23 Psalmu 73 (72) odczytywał on jako symbol ciężaru i nadziei swojego życia. Treści, które odnajdywał w tych wierszach i ukazywał w swoim komentarzu stanowią jakby jego autoportret, szkicowany w obliczu Boga. Są to więc nie tylko pobożne myśli, ale wyjaśnienie wydarzeń jego życia i światło oświecające drogę. To, co napisał Augustyn, wydało mi się przedstawiać moje osobiste przeznaczenie. Psalm, przynależący do tradycji mądrościowej, ukazuje sytuację bycia w potrzebie i cierpieniu, która jest właściwa dla wiary i która wynika z ziemskiego niepowodzenia [...]. Ut iumentum factus sum apud te et ego semper tecum [...]. Augustyn to słowo o bydlęciu ujął trochę inaczej. Łacińskie słowo iumentum oznacza przede wszystkim zwierzęta pociągowe, które służą do pracy w rolnictwie - i w tym dostrzega on obraz samego siebie, obarczonego ciężarem służby biskupiej. „Zwierzęciem pociągowym jestem przed Tobą, dla Ciebie i właśnie w taki sposób jestem przy Tobie”. Wybrał życie uczonego, a Bóg przeznaczył go do pełnienia roli „zwierzęcia pociągowego” - dobrego wołu, który w świecie ciągnie wóz Stwórcy. Jakże często musiał buntować się przeciw wszelkim błahostkom, którymi go obarczano i które przeszkadzały mu w duchowej pracy, traktowanej jako najgłębsze powołanie. I właśnie wtedy ten psalm pomógł mu oddalić całe rozgoryczenie: tak, oczywiście, stałem się zwierzęciem pociągowym, osłem, wołem, ale właśnie w ten sposób jestem blisko Ciebie, służę Tobie i masz mnie w swym ręku. Tak jak zwierzę pociągowe jest bliskie rolnikowi i pomaga mu w pracy, tak i on właśnie w tej pokornej służbie jest bardzo blisko Boga, jest cały w Jego rękach, jest aż do końca Jego narzędziem - inaczej nie mógłby być bliżej swego Pana, nie mógłby być ważniejszy dla Niego. Ten obładowany niedźwiedź, który zastąpił konia - czy bardziej prawdopodobnie muła - św. Korbinianowi, stając się 
wbrew swojej woli jego zwierzęciem pociągowym, czy nie był i czy nie jest obrazem tego, kim powinienem być, i tego, kim jestem? «Jucznym osłem stałem się dla Ciebie i właśnie w ten sposób jestem we wszystkim i zawsze blisko Ciebie» ${ }^{13}$. Do tych samych myśli św. Augustyna o biskupie jako jucznym zwierzęciu Panu nawiązał Benedykt XVI w przemówieniu do swoich rodaków zgromadzonych na Marienplatz w Monachium podczas swej pielgrzymki do Niemiec w 2006 roku, gdy mówił: ,Wybrał życie uczonego, a [...] Bóg go powołał, by służył jako "zwierzę pociągowe», posłuszny wół, który ciągnie pług po Bożym polu, wykonuje ciężką pracę, jaka mu zostaje przydzielona. Lecz potem przyznaje: tak jak zwierzę pociągowe jest bardzo blisko rolnika, pod którego kierunkiem pracuje, tak ja jestem niezwykle blisko Boga, ponieważ w ten sposób służę Mu bezpośrednio do budowania Jego królestwa, do wznoszenia Jego Kościoła. Na podstawie tych myśli Biskupa z Hippony niedźwiedź dodaje mi zawsze na nowo otuchy, by jak przed 30-tu laty tak i teraz przy moich nowych zadaniach, swoją służbę wypełniać z radością i pełnym przekonaniem oraz dzień za dniem wypowiadać Bogu swoje «tak». Stałem się dla Ciebie jucznym zwierzęciem, ale przez to jestem zawsze przy Tobie (Ps 73, 23). Niedźwiedź św. Korbiniana został w Rzymie uwolniony, w moim przypadku Pan postanowił inaczej"14.

Do tak pojmowanej żywej Tradycji nawiązuje dziś ks. Józef Ratzinger jako Benedykt XVI prezentując ją w środowych katechezach audiencjonalnych poprzez przypominanie jej świadków - apostołów, ich następców i postaci z nimi związanych oraz Ojców Kościoła. Po dokończeniu rozpoczętych przez Jana Pawła II katechez, komentujących Psalmy i kantyki Nowego Testamentu, Benedykt XVI rozpoczął w 2. poł. marca 2006 r. i kontynuuje do dziś prezentację wczesnochrześcijańskiej Tradycji w środowych przemówieniach pod następującymi tytułami: Apostołowie świadkami i posłańcami Chrystusa (22 III 2006) ${ }^{15}$, Dar komunii (29 III 2006); Komunia $w$ czasie Tradycja (26 IV 2006), Tradycja Apostolska (3 V 2006), Sukcesja apostolska (10 V 2006), Piotr Rybak (17 V 2006), Piotr Apostot (24 V 2006), Piotr skata, na której Chrystus zbudowat Kościót (7 VI 2006), Andrzej Protóklitos (14 VI 2006), Jakub Starszy (21 VI 2006), Jakub Mtodszy (28 VI 2006), Jan - syn Zebedeusza (5 VII 2006), Jan - prorok z Patmos (23 VIII 2006), Jan Teolog

${ }^{13}$ Ratzinger, s. 128-130; por. Augustinus, Sermo 189, 4 (Frang. 4), w: Miscellanea Agostiniana, ed. G. Morin, I, Roma 1930, 211, 29: „Iumentum ipsius sumus”; Sermo 68, 12 (Mai 76), tamże s. 366, 10: „Si iumentum meum eris - hoc tibi Dominus tuus dicit”; In Joannis epistolam tract. 7, 2, PL 35, 2030: Esto humilis, porta Dominum tuum, est iumentum sessoris tui. Bonum tibi est, ut ipse regat, et ipse ducat"; Sermo 119, PL 38, 671

${ }^{14}$ Saluto rivolto ai fedeli presenti nella Marienplatz in München (9 IX 2006), Insegnamenti di Benedetto XVI, vol. II/2, s. 227, częściowy przekład: OsRomPol 28 (2007) nr 6, s. 3.

15 Por. Benedykt XVI, Swiadkowie Chrystusa. Apostołowie i uczniowie, wprowadzenie W. Chrostowski, Izabelin - Warszawa 2007, wyd. Rosikon Press. 
(9 VIII 2006), Mateusz (30 VIII 2006), Filip (6 IX 2006), Tomasz (27 IX 2006), Bartłomiej (4 X 2006), Szymon Kananejczyk i Juda Tadeusz (11 X 2006), Judasz Iskariota i Maciej (18 X 2006), Pawet - portret człowieka i apostota (25 X 2006), Pawet - centralne miejsce Jezusa Chrystusa (8 XI 2006), Pawet - Duch Święty w naszych sercach (15 XI 2006), Pawet - zycie w Kościele (22 XI 2006), Tymoteusz i Tytus - najblizsi wspótpracownicy Pawła (13 XII 2006), Szczepan - pierwszy męczennik (10 I 2007), Barnaba, Sylas i Apollos (31 I 2007), Małżonkowie - Pryscylla i Akwila (7 II 2007), Kobiety w stużbie Ewangelii (14 II 2007) ${ }^{16}$. Obok nich Papież przypomniał podczas niedzielnej modlitwy na Anioł Pański dwie wybitne postaci Kościoła starożytnego: Augustyn - namiętne poszukiwanie prawdy z milczacym i solidnym wsparciem matki Moniki (27 VIII 2006) ${ }^{17}$ i Grzegorz Wielki-Rzymianin $i$ mnich u zarania nowej cywilizacji (3 IX 2006) ${ }^{18}$.

Po rocznej prezentacji apostołów i wybranych postaci Kościoła Apostolskiego, Benedykt XVI rozpoczął w marcu 2007 r. omawianie sylwetek autorów wczesnochrześcijańskich jako świadków Tradycji i tworzącej się teologii, przypominając krótko chronologicznie ich biogramy i ważniejsze pisma, oraz cenniejsze i po dziś dzień aktualne aspekty ich nauki. Wybiera spośród nich wybitniejszych z historii Kościoła starożytnego rozpoczynając od Ojców Apostolskich, spośród których omawia tylko św. Klemensa Rzymskiego i św. Ignacego Antiocheńskiego, pomijając m.in. Didache i św. Polikarpa, spośród zaś apologetów greckich tylko św. Justyna i św. Ireneusza z pominięciem niemniej ważnych innych postaci. Niżej prezentujemy papieskie katechezy o 11 najstarszych autorach wczesnochrześcijańskich, omówionych do końca czerwca 2007 r., a mianowicie: św. Klemensie Rzymskim, św. Ignacym Antiocheńskim, św. Justynie, św. Ireneuszu, Klemensie Aleksandryjskim, Orygenesie (dwie), Tertulianie, św. Cyprianie, Euzebiuszu z Cezarei, św. Atanazym i św. Cyrylu Jerozolimskim.

Ks. Stanisław Longosz ${ }^{19}$

${ }^{16}$ Ich teksty w oryginalnym brzmieniu włoskim zob. Insegnamenti di Benedetto XVI, vol. II/1-2 pod wskazanymi datami; ich przekład polski zob. OsRomPol 27 (2006) nr 8, s. 34-39 (Apostołowie swiadkowie - Komunia w czasie); nr 9-10, s. 41-45 (Tradycja apostolska - Piotr Rybak); nr 11, s. 53-58 (Piotr Apostot - Jakub Starszy); nr 12, s. 21-29 (Jakub Młodszy-Mateusz); 28 (2007), nr 1, s. 35-42 (Filip-Judasz Iskariota); nr 3, s. 28-38 (Pawet portret-Szczepan); nr 5, s. 49-54 (BarnabaKobiety w Ewangelii).

${ }^{17}$ Por. Insegnamenti di Benedetto XVI, vol. II/2, s. 152-153; przekład OsRomPol 27 (2006) nr 12, s. 30-31 (Św. Monika matka św. Augustyna).

${ }_{18}$ Por. tamże, s. 192-193; OsRomPol 27 (2006) nr 12, s. 31 (Św. Grzegorz Wielki).

19 Ks. S. Longosz zebrał katechezy oraz uzupełnił i dopracował ich komentarz. 